AlphaMath

Journal of Mathematics Education, 7(1) May 2021

\title{
Prediksi Predikat Kelulusan Mahasiswa dengan Rantai Markov dan Faktor-Faktor yang Mempengaruhi Indeks Prestasi Mahasiswa
}

\author{
Arfarani Rosalindari*1, Sufri², Gusmi Kholijah ${ }^{3}$ \\ 1,2,3Program Studi Matematika, Universitas Jambi, Indonesia \\ *rarfarani31@gmail.com
}

\begin{abstract}
ABSTRAK
Indeks Prestasi (IP) mahasiswa mengalami perubahan tiap semesternya, baik kenaikan maupun penurunan. Hal tersebut berpengaruh terhadap IPK yang diperoleh saat kelulusan. IP yang diperoleh mahasiswa pada semester genap saat ini hanya dipengaruhi oleh IP pada semester ganjil sebelumnya. Hal ini sesuai dengan sifat rantai markov, jika ada kejadian masa lalu dan kejadian masa depan, maka kejadian masa depan bersifat bebas terhadap kejadian masa lalu dan hanya terikat pada kejadian saat ini. Rantai markov digunakan untuk menganalisis besarnya peluang perubahan IP mahasiswa tiap semester serta memprediksi predikat kelulusan mahasiswa dengan state space yang digunakan yaitu : predikat cukup memuaskan dengan IPK 2,00 - 2,75 menjadi state 0, predikat memuaskan dengan IPK 2,76 - 3,24 menjadi state 1, predikat sangat memuaskan dengan IPK 3,25 - 3,79 menjadi state 2, dan predikat cumlaude dengan IPK 3,80 - 4,00 menjadi state 3. Penelitian ini bertujuan untuk memprediksi predikat kelulusan mahasiswa serta menganalisis faktor yang berpengaruh signifikan terhadap IP mahasiswa. Regresi dummy digunakan untuk menganalisis faktor yang berpengaruh signifikan terhadap IP mahasiswa dengan faktor-faktor yang diteliti yaitu: sarana dan prasarana kampus, pertemanan, keaktifan dalam organisasi, penggunaan internet, dan uang saku. Hasil penelitian menunjukkan prediksi jumlah mahasiswa dengan predikat kelulusan cukup memuaskan rentang IPK 2,00-2,75 sebesar 0,56\%, mahasiswa yang lulus dengan predikat memuaskan rentang IPK 2,76 - 3,24 sebanyak 7,39\%, mahasiswa yang lulus dengan predikat sangat memuaskan rentang IPK 3,25 - 3,79 sebanyak 54,18\%, dan mahasiswa yang lulus dengan predikat cumlaude rentang IPK $3,80-4,00$ sebanyak 37,87\%. Adapun faktor yang berpengaruh signifikan terhadap IPK mahasiswa yaitu keaktifan dalam organisasi dan penggunaan internet.
\end{abstract}

Kata kunci : Indeks Prestasi (IP), Rantai Markov, State, Variabel Dummy

\begin{abstract}
Students' Achievement Index (IP) changes each semester, both increase and decrease. This affects the GPA obtained by graduation. IP obtained by students in even semester is only influenced by IP in odd semester. Based on nature of Markov Chain, if there are past and future events, then future events are independent of past events and only tied to current events. Markov chain is used to analyze probability of IP change each semester and to predict the predicate of graduation with state space used, namely: satisfactory predicate with GPA of $2.00-2.75$ to state 0 , satisfactory predicate with GPA of $2.76-3,24$ becomes state 1 , predicate is very satisfactory with GPA of $3.25-3.79$ being state 2 , and cumlaude predicate with GPA of $3.80-4.00$ being state 3 . This study aims to predict the predicate of student graduation and to analyze factors that have significant effect on IP. Dummy regression is used to analyze factors that have significant effect on IP with the factors studied, namely: campus facilities and infrastructure, friendship, organizational activeness, internet use, and money. Results showed that predicate of graduation with satisfactory predicate, GPA range of 2.00-2.75 was $0.56 \%$, students who graduated with satisfactory predicate GPA range 2.76-3.24 was 7.39\%, students who graduated with very satisfactory predicate, GPA ranges 3.25-3.79 was 54.18\%, and students who graduated with cumlaude predicate ranged from GPA 3.80-4.00 was $37.87 \%$. Factors that have significant effect on student GPA are activeness in the organization and use of the internet.
\end{abstract}

Key words: Semester Achievement Index, Markov Chain, State, Dummy Variable

Received: 2021-02-24

/Accepted: 2021-04-14

/Published: 2021-05-01

\section{Pendahuluan}

Keberhasilan akademik mahasiswa ditandai dengan prestasi akademik yang dicapai, ditunjukkan melalui Indeks Prestasi (IP) maupun Indeks Prestasi Kumulatif (IPK) serta ketepatan dalam menyelesaikan studi. Indeks Prestasi (IP) mahasiswa tiap semesternya tidak tetap atau mengalami perubahan, baik itu kenaikan maupun penurunan. Hal tersebut berpengaruh terhadap IPK yang diperoleh saat kelulusan. Keberhasilan akademik mahasiswa 
dipengaruhi oleh faktor dari dalam diri mahasiwa (faktor internal) dan faktor dari luar (faktor eksternal). Peluang perubahan IP perlu dianalisis dengan tujuan untuk mengetahui seberapa besar peluang perubahan IP mahasiswa antar kategori IPK, agar dapat diprediksi predikat kelulusan mahasiswa. Kemudian, faktor yang mempengaruhi perubahan IP mahasiswa perlu dianalisis untuk mengetahui faktor yang berpengaruh terhadap perubahan IP mahasiswa, agar dapat dilakukan perbaikan dalam proses pembelajaran.

IP mahasiswa pada waktu ke- $(n+1)$ hanya dipengaruhi oleh IP mahasiswa pada waktu ke- $n$ dan bersifat lepas dari IP mahasiswa pada waktu ke- $(n-1)$. IPK yang diperoleh mahasiswa pada semester genap hanya dipengaruhi oleh IPK pada semester ganjil. Hal tersebut sejalan dengan prinsip rantai markov. Rantai markov merupakan metode yang menganalisis kejadian pada masa mendatang $X_{n+1}$ yang terletak di state $j$ bersyarat atau hanya terikat pada kejadian masa sekarang $X_{n}$ yang terletak di state $i$ dan bersifat lepas dari kejadian-kejadian sebelumnya (Serfozo, 2009). Oleh karena itu, untuk menganalisis besarnya perubahan IP mahasiswa tiap semesternya serta memprediksi predikat kelulusan mahasiswa digunakan metode rantai markov.

Rantai markov adalah suatu proses stokastik dengan state space dan parameter space diskrit dimana kejadian hari ini hanya dipengaruhi kejadian kemarin, atau hanya bergantung pada satu langkah sebelumnya. Rantai markov didefinisikan dengan matriks peluang transisi satu langkah pada state dimana proses dimulai saat nol (Taylor dan Samuel, 1998). Menurut Serfozo (2009) suatu proses stokastik $X=\left\{X_{n} ; n \geq 0\right\}$ dalam bagian yang terhitung $S$ adalah sebuah rantai markov jika $\forall i, j \in S$ dan $n \geq 0$,

$$
\begin{aligned}
& P\left\{X_{n+1}=j \mid X_{0}, \ldots, X_{n}\right\}=P\left\{X_{n+1}=j \mid X_{n}\right\} \\
& P\left\{X_{n+1}=j \mid X_{n}=i\right\}=P_{i j} \ldots \ldots \ldots \ldots \ldots \ldots \ldots
\end{aligned}
$$

dengan:

$X=$ Barisan kejadian

$P=$ Peluang kejadian

$S$ = Indeks set dari kejadian

$n$ = waktu kejadian

Menurut Taylor dan Samuel (1998) suatu rantai Markov dikatakan rantai markov diskrit jika perpindahan kejadian terjadi dalam interval waktu diskrit yang tetap. $X(t)$ dengan $t=$ $1,2,3, \ldots, n$ merupakan himpunan variabel acak kejadian dengan indeks $t$, maka himpunan tersebut dinyatakan sebagai proses stokastik dengan parameter diskrit. Secara matematis, rantai markov diskrit adalah sebagai berikut :

$$
\begin{aligned}
P\left(X_{n+1}=j \mid X_{0}\right. & \left.=i_{0}, \ldots, X_{n-1}=i_{n-1}, X_{n}=i\right) \\
& =P\left(X_{n+1}=j \mid X_{n}=i\right) \ldots \ldots \ldots
\end{aligned}
$$

untuk setiap waktu $n$ dan semua state $i_{0}, \ldots, i_{n-1}, j$.

Peluang transisi satu langkah terjadi dimana kejadian $i$ pada saat $n$ merupakan syarat kejadian $j$ yakni pada saat $n+1$ (Stewart, 2009). Matriks transisi dari rantai markov waktu diskrit $X_{t}, t=0,1, \ldots, n$ dengan ruang kejadian $(0,1,2, \ldots)$ dan peluang transisi dinotasikan dengan $P=P_{i j}$, dengan:

untuk $i=0,1,2, \ldots, N$ dan $j=0,1,2, \ldots, N$

$$
P=\left[\begin{array}{crll}
P_{00} & P_{01} & \ldots & P_{0 N} \\
P_{10} & P_{11} & \ldots & P_{1 N} \\
\vdots & \vdots & \ddots & \vdots \\
P_{N 0} & P_{N 1} & \ldots & P_{N N}
\end{array}\right]
$$


Menurut Taylor dan Samuel (1998) peluang transisi $n$-langkah dinotasikan dengan $P_{i j}{ }^{(n)}$, adalah peluang bersyarat suatu sistem yang berada pada state $i$ akan berada pada state $j$ setelah proses mengalami $n$-transisi, yang rumusnya sebagai berikut:

$$
P_{i j}{ }^{(n)}=P\left\{X_{m+n}=j \mid X_{m}=i\right\}
$$

Menurut Tamudia, dkk (2014) vektor distribusi peluang transisi (state vector) merupakan suatu vektor baris yang berisi nilai-nilai peluang dari masing-masing state. Vektor distribusi peluang transisi di awal periode dinyatakan dengan $x_{0}$ yang menyatakan besarnya peluang transisi dari masing-masing state di awal periode dan jika $P^{n}$ menyatakan matriks peluang transisi langkah $\mathrm{ke}-n$, maka vektor distribusi peluang transisi pada periode ke $-n$ dinyatakan sebagai berikut:

$$
x_{n}=P^{(n)} x_{0}
$$

Selanjutnya, peneliti akan menganalisis faktor yang berpengaruh signifikan terhadap perubahan IPK mahasiswa dengan analisis regresi dummy. Analisis regresi merupakan teknik analisis statistika yang digunakan untuk menjelaskan hubungan suatu variabel respon $Y$ dengan menggunakan satu atau lebih variabel bebas $X$ (Ghozali, 2013). Misalkan hubungan antara peubah respon $Y$ dengan peubah bebas $X$ untuk $i=1,2,3, \ldots, n$ ditentukan oleh:

dengan:

$$
Y=\beta_{0}+\beta_{1} X_{1}+\beta_{2} X_{2}+\cdots+\beta_{k} X_{k}+\varepsilon
$$

$\begin{array}{ll}Y & : \text { Peubah respon } \\ X & : \text { Peubah bebas } \\ \beta_{0} & : \text { Titik potong dengan sumbu } Y \\ \beta_{1} & : \text { Kemiringan dari garis regresi } \\ \varepsilon & : \text { Tingkat kesalahan (error) }\end{array}$

Jika variabel bebas bersifat kualitatif atau berukuran kategori, maka di dalam model regresi variabel tersebut harus dinyatakan sebagai variabel dummy. Variabel dummy digunakan untuk menguji variabel bebas yang berukuran kategori atau non-metrik. Variabel dummy (variabel boneka) yaitu variabel yang mengasumsikan nilai-nilai biner seperti kode 0 (nol) atau 1 (satu) (Gujarati, 2003). Adapun persamaan regresi dengan variabel dummy dinyatakan sebagai berikut (Sembiring, 2003):

$$
Y=\beta_{0}+\beta_{1} D_{1}+\cdots+\beta_{k} D_{k}+\cdots
$$

dengan:

$Y \quad$ : Variabel bebas

$D \quad$ : Variabel dummy sebagai variabel bebas yang bernilai 1 atau 0

$\varepsilon \quad$ : Tingkat kesalahan (error)

Pada penelitian ini, akan dianalisis mengenai perpindahan atau perubahan IPK mahasiswa Program S1 Jurusan MIPA FST UNJA angkatan 2018 yang didasarkan pada IPK semester ganjil dan semester genap serta dapat memprediksi predikat kelulusan mahasiswa berdasarkan perubahan yang diperoleh dan juga menganalisis faktor-faktor yang mempengaruhi IPK mahasiswa.

\section{Metodologi Penelitian}

Penelitian dilakukan pada 11 Desember 2020 sampai 13 Desember 2020 di Program S1 Jurusan MIPA Fakultas Sains dan Teknologi Universitas Jambi. Jenis data yang digunakan pada penelitian ini berupa data kuantitatif berupa data indeks prestasi mahasiswa dari semester 1 hingga semester 4 yang sumber datanya diperoleh langsung dari hasil angket yang disebarkan kepada mahasiswa Program S1 Jurusan MIPA Fakultas Sains dan Teknologi Universitas Jambi 
angkatan 2018.

Tabel 1. Klasifikasi State

\begin{tabular}{ccc}
\hline State & Predikat Kelulusan & Rentang IPK \\
\hline 0 & Cukup Memuaskan & $2,00-2,75$ \\
1 & Memuaskan & $2,76-3,24$ \\
2 & Sangat Memuaskan & $3,25-3,79$ \\
3 & Dengan Pujian (Cumlaude) & $3,80-4,00$ \\
\hline
\end{tabular}

Adapun variabel bebas dan variabel respon pada penelitian ini adalah sebagai berikut:

Tabel 2. Definisi Variabel Penelitian

\begin{tabular}{cll}
\hline Notasi & \multicolumn{1}{c}{ Definisi } & Skala \\
\hline$Y$ & $\begin{array}{l}\text { Indeks Prestasi Kumulatif (IPK) Mahasiswa sebagai variabel } \\
\text { respon }\end{array}$ & Interval \\
$X_{1}$ & $\begin{array}{l}\text { Sarana dan prasarana kampus sebagai variabel bebas dengan } \\
\text { kategori puas dan tidak puas } \\
X_{2}\end{array}$ & $\begin{array}{l}\text { Pertemanan sebagai variabel bebas dengan kategori baik dan } \\
\text { tidak baik }\end{array}$ \\
$X_{3}$ & $\begin{array}{l}\text { Keaktifan dalam organisasi sebagai variabel bebas dengan } \\
\text { kategori setuju dan tidak setuju }\end{array}$ & Ordinal \\
$X_{4}$ & $\begin{array}{l}\text { Penggunaan internet sebagai variabel bebas dengan kategori baik } \\
\text { dan tidak baik }\end{array}$ & Ordinal \\
$X_{5}$ & $\begin{array}{l}\text { Uang saku sebagai variabel bebas dengan kategori setuju dan } \\
\text { tidak setuju }\end{array}$ & Ordinal \\
\hline
\end{tabular}

\section{Hasil dan Pembahasan}

Perubahan IPK mahasiswa pada semester ganjil (semester I) dan semester genap (semester II) akan dianalisis perubahannya dari suatu state IPK ke state IPK lainnya. Adapun data yang telah diperoleh yakni sebagai berikut:

Tabel 3. Jumlah Mahasiswa pada Masing-Masing State di Semester Ganjil dan Semester Genap

\begin{tabular}{ccccccccc}
\hline $\begin{array}{c}\text { Program } \\
\text { Studi }\end{array}$ & \multicolumn{2}{c}{ Matematika } & \multicolumn{2}{c}{ Kimia } & \multicolumn{2}{c}{ Biologi } & \multicolumn{2}{c}{ Fisika } \\
\hline Semester & I & II & I & II & I & II & I & II \\
\hline 0 & 0 & 2 & 0 & 0 & 1 & 0 & 1 & 0 \\
1 & 10 & 9 & 9 & 0 & 4 & 1 & 4 & 3 \\
2 & 14 & 10 & 7 & 16 & 9 & 13 & 6 & 8 \\
3 & 4 & 7 & 4 & 4 & 2 & 2 & 1 & 1 \\
Jumlah & \multicolumn{2}{c}{28} & \multicolumn{2}{c}{20} & \multicolumn{2}{c}{16} & \multicolumn{2}{c}{12} \\
\hline
\end{tabular}

Pada Tabel 2 menunjukkan jumlah mahasiswa tiap program studi pada masing-masing state di semester ganjil dan semester genap. Perpindahan jumlah mahasiswa pada masing-masing state diperoleh dengan cara menganalisis jumlah mahasiswa pada masing-masing state di semester ganjil dan semester genap, kemudian jumlah mahasiswa yang diperoleh dikelompokkan pada masing-masing pola perpindahan antar state. Oleh karena itu, perpindahan jumlah mahasiswa secara rinci disajikan pada tabel di bawah ini. 
Tabel 4. Pola Perpindahan Jumlah Mahasiswa pada Masing-Masing State

\begin{tabular}{|c|c|c|c|c|c|}
\hline $\mathrm{I}_{\mathrm{I}} \mathrm{II}$ & 0 & 1 & 2 & 3 & $\begin{array}{c}\text { Jumlah } \\
\text { Semester I }\end{array}$ \\
\hline 0 & 0 & 1 & 1 & 0 & 2 \\
\hline 1 & 2 & 9 & 16 & 0 & 27 \\
\hline 2 & 0 & 3 & 28 & 5 & 36 \\
\hline 3 & 0 & 0 & 2 & 9 & 11 \\
\hline Jumlah Semester II & 2 & 13 & 47 & 14 & 76 \\
\hline
\end{tabular}

Data pada Tabel 4 merupakan pola perpindahan jumlah mahasiswa pada masing-masing state diperoleh dengan cara menganalisis jumlah mahasiswa pada masing-masing state di semester ganjil dan semester genap, kemudian jumlah mahasiswa yang diperoleh dikelompokkan pada masing-masing pola perpindahan antar state. Nilai-nilai pada tabel di atas digunakan untuk menganalisis seberapa besar peluang perpindahan atau peluang transisinya. Nilai-nilai peluang transisi yang diperoleh disajikan dalam matriks peluang transisi $P_{i j}$ sebagai berikut:

$$
P_{i j}=\begin{aligned}
& 0 \\
& 1 \\
& 2 \\
& 3
\end{aligned}\left[\begin{array}{cccc}
0 & 1 & 2 & 3 \\
0 & 0,5 & 0,5 & 0 \\
0,0741 & 0,3333 & 0,5926 & 0 \\
0 & 0,0833 & 0,7778 & 0,1389 \\
0 & 0 & 0,1818 & 0,8182
\end{array}\right]
$$

Selanjutnya, ditentukan vektor distribusi peluang transisi di awal periode. Nilai distribusi peluang transisi digunakan untuk menghitung besaran peluang jumlah mahasiswa pada masingmasing state di tiap semesternya. Sehingga diperoleh vektor distribusi peluang transisi sebagai berikut:

$$
x_{0}=\left[\begin{array}{llll}
0,0263 & 0,1711 & 0,6184 & 0,1842
\end{array}\right]
$$

Prediksi jumlah mahasiswa pada tiap state dapat dilakukan dengan berdasarkan pada nilai vektor distribusi peluang transisi $x_{0}$ yang telah diperoleh dapat di cari vektor distribusi peluang transisi untuk beberapa semester mendatang. Adapun prediksi yang akan dilakukan yakni pada saat kelulusan mahasiswa yaitu pasa semester 8 . Sehingga, diperoleh hasil sebagai berikut :

$$
x_{7}=\left[\begin{array}{llll}
0,0056 & 0,0739 & 0,5418 & 0,3787
\end{array}\right]
$$

Vektor distribusi peluang transisi $x_{7}$ merupakan hasil prediksi jumlah mahasiswa pada masingmasing predikat kelulusan mahasiswa Program S1 Jurusan MIPA FST UNJA Angkatan 2018 yang dinyatakan dengan besaran peluang jumlah mahasiswa pada masing-masing state di semester 8 . Besar peluang jumlah mahasiswa pada state 0 yakni 0,0056 atau $0,56 \%$, peluang jumlah mahasiswa pada state 1 sebesar 0,0739 atau 7,39\%, peluang jumlah mahasiswa pada state 2 sebesar 0,5418 atau 54,18\%, dan besar peluang jumlah mahasiswa pada state 3 sebesar 0,3787 atau $37,87 \%$.

Setelah dilakukan prediksi jumlah mahasiswa pada masing-masing kategori predikat kelulusan diperoleh hasil bahwa terdapat mahasiswa yang berpindah dari suatu state ke state lainnya pada semester ganjil dan semester genap. Sehingga berpengaruh terhadap prediksi persentase jumlah mahasiswa pada tiap kategori predikat kelulusan. Oleh karena itu, diperlukan analisis lanjutan untuk mengetahui faktor-faktor yang berpengaruh signifikan terhadap perubahan IPK mahasiswa. Analisis lanjutan untuk mengetahui faktor-faktor yang berpengaruh terhadap perubahan IPK yakni dengan menggunakan analisis regresi dummy. Data yang digunakan diperoleh dari pendapat responden mengenai variabel-variabel dalam penelitian ini yang 
disebarkan melalui kuisioner. Data yang telah diperoleh dari kuisioner harus dilakukan uji asumsi telebih dahulu dengan tujuan untuk mengetahui apakah data yang diperoleh layak untuk digunakan dalam analisis regresi dummy.

\section{Uji Asumsi Klasik}

\section{Uji Normalitas}

bertujuan untuk mengetahui data variabel bebas dan variabel respon berdistribusi normal. Uji normalitas dapat dilakukan dengan menggunakan Uji Kolmogorov Smirnov. Uji Kolmogorov Smirnov dilakukan dengan membandingkan nilai Kolmogorov Smirnov yang diperoleh dari perhitungan $\left(K S_{\text {hitun }}\right)$ dengan nilai kritis Kolomogorov Smirnov pada tabel kolmogorov smirnov $\left(K S_{\text {tabel }}\right)$. Adapun pengujian normalitas yaitu sebagai berikut:

Hipotesis :

$H_{0}$ : Data tidak berdistribusi normal

$H_{1}$ : Data berdistribusi normal

Taraf signifikansi $(\alpha)=10 \%=0,10$

Kriteria keputusan : $H_{0}$ ditolak jika $K S_{\text {hitu }}<K S_{\text {tabel }}$

Setelah dilakukan analisis diperoleh nilai $K S_{\text {hit }} \quad$ sebesar 0,081 dengan nilai $K S_{\text {tabel }}$ sebesar 1,399, sehingga $K S_{\text {hitung }}<K S_{\text {tabel }}$, dengan keputusan $H_{0}$ ditolak. Hal ini mengartikan bahwa data residual pada penelitian ini berdistribusi normal.

\section{Uji Multikolinearitas}

Uji multikolinearitas bertujuan untuk menguji apakah pada model regresi ditemukan adanya korelasi antara variabel bebas. Adapun cara untuk melihat terjadinya multikolinearitas yakni sebagai berikut :

Hipotesis :

$H_{0}$ : Terjadi multikolinearitas pada data

$H_{1}$ : Tidak terjadi multikolinearitas pada data

Taraf signifikansi $(\alpha)=10 \%=0,10$

Kriteria keputusan : $H_{0}$ ditolak jika $V I F<10$ atau tolerance $>0,10$

Tabel 5. Uji Multikolinearitas

\begin{tabular}{|c|c|c|c|c|c|}
\hline \multirow[b]{2}{*}{ Model } & & $\begin{array}{r}\text { Colline } \\
\text { Statist }\end{array}$ & $\begin{array}{l}\text { rity } \\
\text { cs }\end{array}$ & \multirow[t]{2}{*}{ Keputusan } & \multirow[t]{2}{*}{ Arti } \\
\hline & & Tolerance & VIF & & \\
\hline \multirow[t]{6}{*}{1} & (Constant) & & & & \\
\hline & $\begin{array}{c}\text { Sarana dan Prasarana } \\
\text { Kampus }\end{array}$ & 0.73 & 1.370 & Tolak $H_{0}$ & $\begin{array}{c}\text { Tidak terjadi } \\
\text { multikolinearitas }\end{array}$ \\
\hline & Pertemanan & 0.608 & 1.644 & Tolak $H_{0}$ & $\begin{array}{c}\text { Tidak terjadi } \\
\text { multikolinearitas }\end{array}$ \\
\hline & Keaktifan dalam Organisasi & 0.852 & 1.174 & Tolak $H_{0}$ & $\begin{array}{c}\text { Tidak terjadi } \\
\text { multikolinearitas }\end{array}$ \\
\hline & Penggunaan Internet & 0.993 & 1.007 & Tolak $H_{0}$ & $\begin{array}{c}\text { Tidak terjadi } \\
\text { multikolinearitas }\end{array}$ \\
\hline & Uang Saku & 0.717 & 1.395 & Tolak $H_{0}$ & $\begin{array}{c}\text { Tidak terjadi } \\
\text { multikolinearitas }\end{array}$ \\
\hline
\end{tabular}

\section{Uji Heteroskedastisitas}

Adapun cara untuk melihat terjadinya heteroskedastisitas yakni dengan Uji Glejser. Uji Glejser dilakukan dengan menganalisis regresikan variabel-variabel bebas terhadap nilai absolut 
(mutlak) residualnya (Gujarati, 2004). Uji Glejser dilakukan dengan membandingkan nilai signifikansi dengan taraf signifikansi. Adapun cara untuk melihat terjadinya heteroskedastisitas dengan Uji Glejser yakni sebagai berikut:

Hipotesis :

$H_{0}$ : Terjadi heteroskedastisitas pada data

$H_{1}$ : Tidak terjadi heteroskedastisitas pada data

Taraf signifikansi $(\alpha)=10 \%=0,10$

Kriteria keputusan : $H_{0}$ ditolak jika Sig. $>\alpha$

Tabel 6. Uji Heteroskedastisitas

\begin{tabular}{|c|c|c|c|c|}
\hline Model & & Sig. & Keputusan & Arti \\
\hline \multirow[t]{6}{*}{1} & (Constant) & & & \\
\hline & $\begin{array}{c}\text { Sarana dan Prasarana } \\
\text { Kampus }\end{array}$ & 0.735 & Tolak $H_{0}$ & $\begin{array}{c}\text { Tidak terjadi } \\
\text { heteroskedastisitas }\end{array}$ \\
\hline & Pertemanan & 0.451 & Tolak $H_{0}$ & $\begin{array}{c}\text { Tidak terjadi } \\
\text { heteroskedastisitas }\end{array}$ \\
\hline & Keaktifan dalam Organisasi & 0.351 & Tolak $H_{0}$ & $\begin{array}{c}\text { Tidak terjadi } \\
\text { heteroskedastisitas }\end{array}$ \\
\hline & Penggunaan Internet & 0.538 & Tolak $H_{0}$ & $\begin{array}{c}\text { Tidak terjadi } \\
\text { heteroskedastisitas }\end{array}$ \\
\hline & Uang Saku & 0.127 & Tolak $H_{0}$ & $\begin{array}{c}\text { Tidak terjadi } \\
\text { heteroskedastisitas }\end{array}$ \\
\hline
\end{tabular}

\section{Uji Autokorelasi}

Uji autokorelasi dapat dilakukan dengan menggunakan Runs Test. Uji ini digunakan untuk menguji apakah antar residual terdapat korelasi yang tinggi. Pengambilan keputusan dilakukan dengan membandingkan nilai $Z_{\text {hitung }}$ dan nilai $Z_{\text {tabel }}$. Nilai $Z_{\text {tabel }}$ yang diperoleh sebesar 1,645. Adapun cara untuk melihat terjadinya autokorelasi yakni sebagai berikut:

Hipotesis :

$H_{0}$ : Terjadi autokorelasi pada data residual

$H_{1}$ : Tidak terjadi autokorelasi pada data residual

Taraf signifikansi $(\alpha)=10 \%=0,10$

Kriteria keputusan : $H_{0}$ ditolak jika $-Z_{\text {tabel }}<Z_{\text {hitung }}<Z_{\text {tabel }}$

Setelah dilakukan Runs Test diperoleh nilai $Z_{\text {hitu }}$ sebesar 0,693 dengan niilai $Z_{\text {tabel }}$ sebesar 1,645, sehingga $-Z_{\text {tabel }}<Z_{\text {hit }}<Z_{\text {tabel }}$, dengan keputusan $H_{0}$ ditolak. Hal ini mengartikan bahwa tidak terdapat autokorelasi pada data residual, maka data residual bersifat acak.

\section{Model Regresi Dummy}

Pada analisis regresi dummy digunakan data pendapat responden mengenai faktor-faktor terhadap perubahan IPK mahasiswa yang digunakan untuk analisis regresi. Adapun model regresi dummy yang diperoleh yakni sebagai berikut :

$$
Y=2,916+0,294 D_{1} X_{1}-0,165 D_{2} X_{2}-0,195 D_{3} X_{3}+0,369 D_{4} X_{4}+0,215 D_{5} X_{5}+\varepsilon
$$

Berdasarkan analisis yang telah dilakukan diperoleh nilai $R$ Square sebesar 0,125 , hal ini berarti $12,5 \%$ IPK mahasiswa dapat dijelaskan oleh kelima variabel bebas yaitu sarana dan prasarana kampus, pertemanan, keaktifan dalam organisasi, penggunaan internet, dan uang saku. Sedangkan sisanya dijelaskan oleh faktor-faktor lain di luar model. 


\section{Uji F (Simultan)}

Uji F dilakukan untuk mengetahui pengaruh variabel bebas dalam model berpengaruh secara bersama-sama terhadap variabel respon. Adapun cara untuk melakukan Uji F (simultan) yakni sebagai berikut :

Hipotesis :

$H_{0}: \beta_{k}=0, \quad k=0,1,2,3,4,5$ (Tidak ada pengaruh sarana dan prasarana kampus $\left(X_{1}\right)$, pertemanan

secara

$\left(X_{2}\right)$, keaktifan dalam organisasi $\left(X_{3}\right)$,penggunaan internet $\left(X_{4}\right)$, uang saku $\left(X_{5}\right)$ simultan terhadap IPK mahasiswa $(Y))$

$H_{1}: \beta_{k} \neq 0, \quad k=0,1,2,3,4,5$ (Ada pengaruh sarana dan prasarana kampus $\left(X_{1}\right)$, pertemanan $\left(X_{2}\right)$,

simultan

keaktifan dalam organisasi $\left(X_{3}\right)$, penggunaan internet $\left(X_{4}\right)$, uang saku $\left(X_{5}\right)$ secara

$$
\text { terhadap IPK mahasiswa }(Y))
$$

Taraf signifikansi $(\alpha)=10 \%=0,10$

Kriteria keputusan : $H_{0}$ ditolak jika $F_{\text {hitung }}>F_{\text {tab }}$

Setelah dilakukan Uji F diperoleh nilai derajat bebas $n_{1}=5$ dan $n_{2}=70$, sehingga diperoleh nilai $F_{\text {tabel }}$ sebesar 1,93 serta diperoleh nilai $F_{\text {hitung }}$ sebesar 1,996, sehingga $F_{\text {hitu }}>F_{\text {tabel }}$, dengan keputusan $H_{0}$ ditolak. Maka dapat disimpulkan bahwa variabel bebas secara simultan berpengaruh signifikan terhadap variabel respon.

Uji t (Parsial)

Uji t dilakukan untuk mengetahui pengaruh variabel bebas (sarana dan prasarana kampus, pertemanan, keaktifan dalam organisasi, penggunaan internet, dan uang saku) secara parsial terhadap variabel respon (IPK mahasiswa). Adapun nilai $t_{\text {tabel }}$ dari data penelitian ini sebesar 1,66660. Adapun cara untuk melakukan Uji t (parsial) yakni sebagai berikut :

Variabel sarana dan prasarana kampus $\left(X_{1}\right)$

Hipotesis :

$H_{0}$ : Tidak ada pengaruh sarana dan prasarana kampus $\left(X_{1}\right)$ terhadap IPK mahasiswa $(Y)$

$H_{1}$ : Ada pengaruh sarana dan prasarana kampus $\left(X_{1}\right)$ terhadap IPK Mahasiswa $(Y)$

Variabel pertemanan $\left(X_{2}\right)$

Hipotesis :

$H_{0}$ : Tidak ada pengaruh pertemanan $\left(X_{2}\right)$ terhadap IPK mahasiswa $(Y)$

$H_{1}$ : Ada pengaruh pertemanan $\left(X_{2}\right)$ terhadap IPK Mahasiswa $(Y)$

Variabel keaktifan dalam organisasi $\left(X_{3}\right)$

Hipotesis :

$H_{0}$ : Tidak ada pengaruh keaktifan dalam organisasi $\left(X_{3}\right)$ terhadap IPK mahasiswa $(Y)$

$H_{1}$ : Ada pengaruh keaktifan dalam organisasi $\left(X_{3}\right)$ terhadap IPK Mahasiswa $(Y)$

Variabel penggunaan internet $\left(X_{4}\right)$

Hipotesis :

$H_{0}$ : Tidak ada pengaruh penggunaan internet $\left(X_{4}\right)$ terhadap IPK mahasiswa $(Y)$

$H_{1}$ : Ada pengaruh penggunaan internet $\left(X_{4}\right)$ terhadap IPK Mahasiswa $(Y)$

Variabel uang saku $\left(X_{5}\right)$

Hipotesis :

$H_{0}$ : Tidak ada pengaruh uang saku $\left(X_{5}\right)$ terhadap IPK mahasiswa $(Y)$

$H_{1}$ : Ada pengaruh uang saku $\left(X_{5}\right)$ terhadap IPK Mahasiswa $(Y)$

Taraf signifikansi $(\alpha)=10 \%=0,10$ 
Kriteria keputusan : $H_{0}$ ditolak jika $t_{\text {hitu }}>t_{\text {tabel }}$

Adapun hasil yang diperoleh yaitu :

Tabel 7. Uji t

\begin{tabular}{|c|c|c|c|c|c|}
\hline Model & & $\mathrm{t}$ & Sig. & Keputusan & Arti \\
\hline \multirow[t]{6}{*}{1} & (Constant) & 9.581 & 0 & & \\
\hline & $\begin{array}{c}\text { Sarana dan Prasarana } \\
\text { Kampus }\end{array}$ & 1.200 & 0.234 & Terima $H_{0}$ & Tidak berpengaruh \\
\hline & Pertemanan & -1.113 & 0.269 & Terima $H_{0}$ & Tidak berpengaruh \\
\hline & Keaktifan dalam Organisasi & -2.023 & 0.047 & Tolak $H_{0}$ & $\begin{array}{l}\text { Berpengaruh } \\
\text { signifikan }\end{array}$ \\
\hline & Penggunaan Internet & 1.755 & 0.084 & Tolak $H_{0}$ & $\begin{array}{l}\text { Berpengaruh } \\
\text { signifikan }\end{array}$ \\
\hline & Uang Saku & 1.756 & 0.083 & Tolak $H_{0}$ & $\begin{array}{l}\text { Berpengaruh } \\
\text { signifikan }\end{array}$ \\
\hline
\end{tabular}

\section{Interpretasi Model Regresi Dummy}

Setelah dilakukan analisis regresi dummy terhadap semua model variabel bebas, maka diperoleh model terbaik yaitu $Y=2,916-0,195 D_{3} X_{3}+0,369 D_{4} X_{4}+0,215 D_{5} X_{5}+\varepsilon$ yang mengartikan bahwa keaktifan dalam organisasi, penggunaan internet dan uang saku bepengaruh terhadap IPK mahasiswa. Adapun hasil akhir dari penelitian ini berupa model regresi dummy dengan menggunakan variabel yang berpengaruh yaitu variabel $X_{3}$ (keaktifan dalam organisasi), $X_{4}$ (penggunaan internet) dan $X_{5}$ (uang saku) adalah sebagai berikut :

Pada variabel keaktifan dalam organisasi menunjukkan nilai $t_{\text {hitung }}$ sebesar 2,002 $>1,66660$, artinya variabel keaktifan dalam organisasi berpengaruh terhadap IPK mahasiswa. Pada variabel penggunaan internet menunjukkan nilai $t_{\text {hitun }}$ sebesar 1,774 $>1,66660$, artinya variabel penggunaan internet berpengaruh terhadap IPK mahasiswa. Pada variabel uang saku menunjukkan nilai $t_{\text {hitun }}$ sebesar $1,576>1,66660$, artinya variabel uang saku tidak berpengaruh terhadap IPK mahasiswa.

Berdasarkan analisis yang telah dilakukan, maka dapat disimpulkan bahwa variabel keaktifan dalam organisasi dan variabel penggunaan internet berpengaruh terhadap IPK mahasiswa. Sehingga dapat dibentuk model regresi terbaik yaitu sebagai berikut :

$$
Y=3,081-0,192 D_{3} X_{3}+0,372 D_{4} X_{4}+\varepsilon
$$

Model regresi diatas dilakukan uji koefisien determinasi untuk menganalisis ukuran keterkaitan antara variabel bebas terhadap variabel respon dengan hasil yang diperoleh nilai $R$ Square sebesar 0,102, hal ini berarti keragaman IPK mahasiswa dapat dijelaskan oleh variabel keaktifan dalam organisasi dan variabel penggunaan internet sebesar 10,2\% sedangkan 89,8\% keragaman IPK mahasiswa dijelaskan oleh variabel lain yang tidak termasuk dalam model terbaik atau model dengan variabel yang berpengaruh.

\section{Simpulan}

Prediksi predikat kelulusan mahasiswa pada semester 8 yang memperoleh predikat cukup memuaskan sebesar 0,55\%, predikat memuaskan sebesar 7,26\%, dengan predikat sangat memuaskan sebesar 53,68\%, dan yang memperoleh predikat dengan pujian (cumlaude) sebesar 38,51\%. Serta faktor yang mempengaruhi Indeks Prestasi Kumulatif (IPK) mahasiswa 
Program S1 Jurusan MIPA FST UNJA Angkatan 2018 adalah keaktifan dalam organisasi dan penggunaan internet dengan nilai $R$ Square sebesar 0,102 atau $10,2 \%$.

\section{Daftar Pustaka}

Ghozali, I. (2013). Aplikasi Analisis Multivariate dengan Program IBM SPSS, Edisi 7. Universitas Diponegoro. Semarang.

Gujarati, D. N. (2003). Basic Econometric Analysis. New York : Pretince Hall International, Inc.

Mujiastuti, A.I.C dan Fiska, I. (2015). Pengaruh Pertemanan Sebaya Terhadap Prestasi Belajar Pendidikan Agama Islam Siswa Kelas XI SMA Negeri 1 Sewon, Bantul Tahun Pelajaran 2013/2014. Jurnal Literasi, 6(1).

Murniarti, D., Endang, P dan Sri, B. (2016). Pengaruh Sarana dan Prasarana Terhadap Hasil Belajar Siswa Pelajaran Ekonomi SMA Negeri 1 Sungai Ambawang. Jurnal Pendidikan dan Pembelajaran Khatulistiwa, 5(11), 2715-2723.

Napsiah. (2012). Pengaruh Uang Saku Terhadap Hasil Belajar Siswa di Sekolah Menengah Pertama Islam Terpadu (SMPIT) Assy-Assyukriyah Cipondoh Kota Tangerang. Skripsi. Universitas Islam Syekh Yusuf. Tangerang.

Pratiwi, D. R. (2012). Pengaruh Pemanfaatan Internet Terhadap Hasil Belajar Siswa Kelas XI Pada Mata Pelajaran Teknologi Informasi dan Komunikasi di SMA Negeri 1 Pengasih. Skripsi. Universitas Negeri Yogyakarta. Yogyakarta.

Putri, C. E. (2017). Pengaruh Keaktifan Mahasiswa Dalam Organisasi Terhadap Prestasi Belajar Mahasiswa Jurusan Pendidikan Agama Islam (PAI) Institut Agama Islam Negeri Metro Tahun Akademik 2016/2017. Skripsi. Institut Agama Islam Negeri (IAIN) Metro. Lampung.

Sembiring, R.K. (2003). Analisis Regresi. ITB. Bandung.

Serfozo, R. (2009). Basics of Applied Stochastic Processes. Springer. Heidelberg.

Stewart, W. J. (2009). Probability Markov Chains Queues and Simulation. Princeton University Press. New Jersey.

Tamudia, D., Johanes, L dan Julia, T. (2014). Analisis Rantai Markov Untuk Memprediksi Perpindahan Merek Shampoo di Hypermart Swalayan Manado Town Square. Jurnal Matematika dan Aplikasi d'Cartesian, 3(1).

Taylor, H.M. dan Samuel, K. (1998). An Introduction to Stochastic Modeling Third Edition. Academic Press. California.

Universitas Jambi. (2020). Peraturan Rektor Universitas Jambi Nomor 9 Tahun 2020 Tentang Peraturan Akademik Universitas Jambi. Universitas Jambi. Jambi. 